\title{
LISTENING TO THE VOICE OF PRIMARY STAKEHOLDERS - DIFFERENCES OF MEASURING QUALITY AMONG THE OPERATION LEVELS OF HIGHER EDUCATION INSTITUTIONS
}

\author{
Surman V. ${ }^{1^{*}}$, Tóth Zs. E. ${ }^{2}$ \\ ${ }^{1}$ Department of Management and Business Economics, Faculty of Economic and Social Sciences, Budapest \\ University of Technology and Economics, Hungary \\ ${ }^{2}$ Faculty of Economics and Business, John von Neumann University, Hungary \\ https://doi.org/10.47833/2020.2.ECO.001
}

\author{
Keywords: \\ higher education \\ quality \\ measurement levels \\ dimensions \\ stakeholders
}

\section{Article history:}

Received 21 September 2019

Revised 29 October 2019

Accepted 15 November 2019

\begin{abstract}
The growing number of students enrolled in higher education and of the offered courses increasingly emphasizes the need for student-focused activities. Therefore, if sufficient attention is not paid to the evaluation of educational services and to the analyses of the results obtained, the quality of higher education services provided to students as key customers becomes unmanageable. In order to gain competitive advantage in the higher education sector where increasing marketization takes place, institutions have to identify their primary stakeholders as well as their needs and expectations. However, they should not only focus on students, since there are many other stakeholder groups involved in the key processes including e.g. academic staff with whom students have direct interactions and perceive educational service quality primarily through their lecturers' activity. When examining the quality of institutional services, different levels of measurement can be distinguished to each of which primary stakeholders, customers and quality dimensions could be identified. At all three levels (including institutional, program / faculty, course level), the state of the art focuses primarily on the voice of students and lecturers. In this research, the differences and similarities between the three aforementioned levels are demonstrated from the viewpoints of students and lecturers. As a result, three groups of quality attributes are identified on which quality measurement issues should be focused at each level.
\end{abstract}

\section{Introduction}

The role of higher education (HE) has been growingly recognized when developing a competitive socio-economic system (Kováts, 2016). Therefore, in the last two decades a renewed attention has been paid to the higher education sector, the various quality issues of institutional operation and of its different levels have come to the forefront (e.g. Mizikaci, 2006; Gupta \& Kaushik, 2018). Diverse quality evaluation methods have arisen due to the increasing stakeholder requirements associated with institutional quality (Kováts \& Takács, 2016).

\footnotetext{
* Corresponding author. Tel.: +36 1234632459

E-mail address: surman@mvt.bme.hu
} 
Despite the increasing attention paid to quality issues, the difficulty of defining quality in higher educational context may act as a barrier when it comes to the enhancement of institutional performance towards total quality management (TQM) philosophy (Olaskoaga-Larrauri et al., 2016). Olaskoaga-Larrauri et al. (2016) compared different studies (such as CESPUALE and ECUALE) when providing a viable quality definition. Based on the comparison of the voice of deans and academic staff, quality definitions such as 'Quality consists of meeting the expectations of all stakeholders (students, lecturers, institutions, society)' and 'Quality consists of developing the capabilities of students to help them transform themselves' have been pointed out. The first definition highlights that besides the students' viewpoint other stakeholders' expectations should also be taken into account, while the second definition expresses that the approach of evaluating quality has shifted institutions away from considering students as passive recipients towards handling them as co-creators of knowledge while widening the platform of stakeholders whose 'voice' counts. The higher educational service is considered as a unique service due to the interaction between different stakeholder groups the attending participants of which are changing from semester to semester. The variability of the service provision is caused by the ever increasing needs and expectations of the different stakeholders and by their unique and unstandardized experience gained during the 'consumption' of HE services. Higher education is also unique in the sense that its primary customers, namely students, do not have a clear idea of what they are about to "purchase" calling attention to the fact that they cannot be the sole judge of HE quality (Gilroy et al., 1999).

The paper is structured as follows. Section 2 gives an overview of HE stakeholders. Section 3 introduces the applied methodology to differentiate the three operation levels associated with viewing quality at different levels of institutional operation. Section 4 interprets the first results of a student survey and some focus group interviews. Section 5 summarizes the main managerial conclusions and outlines possible future research directions.

\section{Stakeholders of higher education institutions}

Defining service quality is not an easy task without having a bright picture of the different groups of stakeholders. According to the state of the art, stakeholders of HE include undergraduate students, graduates, university employees, labor market participants, funding bodies and foundations, scientific societies, government, society, etc. (Guolla, 1999; Clayson \& Haley, 2005; Bennett \& AliChoudhury, 2009; Mark, 2013; Nell \& Cant, 2014; Fosu \& Owusu, 2015; Guilbault, 2016; Bhuian, 2016; Nasim et al., 2019; Ruben et al., 2018; Mattah et al., 2018). What is more, the groups of stakeholders who should be considered and their weighting may vary according to the level of operation examined in a particular HE situation. Fassin (2009) and Mainardes et al. (2012) introduced analytical models defining different stakeholder groups. Fassin (2009) divided the group of potential stakeholders into three subgroups: stakeholders (internal constituents), stakewatchers (pressure group) and stakekeepers (regulators). True stakeholders can be characterized by having a real, direct claim on the institution, while a pressure group only has an indirect one. Regulators have no real claims at all. Mainardes et al. (2012) identified six groups of stakeholders, but highlighted the complexity of defining the borders among the groups:

- Regulatory stakeholder: this stakeholder group has influence over the organization, but the organization has none or very little influence.

- Controller stakeholder: the organization and the stakeholder are influenced by each other, however, the stakeholder's influence is higher on the organization.

- Partner stakeholder: the organization and the stakeholder are similarly influenced by each other.

- Passive stakeholder: the organization and the stakeholder have an impact on each other, the influence of the organization is higher on the stakeholder.

- Dependent stakeholder: the organization has an influence over the stakeholder, but the stakeholder has none or very little influence.

- Non-stakeholder: the organization and the stakeholder do not influence each other.

Based on the above mentioned studies, stakeholders of HE institutions could be grouped by following the previous classification. Table 1 implies that the borders are blurred among the stakeholder groups. Depending on the operational level, the situation and the investigated process, 
the participants of the higher education institution (HEI) processes can have different roles, provide different input and receive different output. Table 1 shows that students can be partner, passive or dependent stakeholder depending on the force of their influence on the university. University staff could be present in almost every role depending on the position of the staff member and the process. The society is present in various roles (controller, partner or passive stakeholder) as well as the parents of students (partner, passive, dependent stakeholder). Except the evaluation and assessment bodies, all defined participants could be part of more than one stakeholder group of Mainardes et al. (2012) which could be realized on the process shown in Figure 2.

Table 1. Groups of stakeholders in higher education

\begin{tabular}{|c|c|c|c|c|c|c|c|c|}
\hline Participants of HEI processes & $\begin{array}{l}\frac{\bar{d}}{\frac{0}{0}} \\
\frac{0}{d} \\
\frac{\pi}{0} \\
\frac{\pi}{\omega}\end{array}$ & $\begin{array}{l}\bar{d} \\
\frac{d}{d} \\
\frac{0}{0} \\
\frac{d}{d} \\
\omega\end{array}$ & 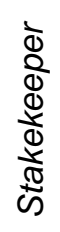 & 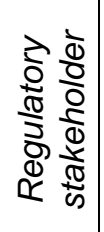 & 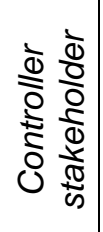 & 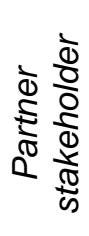 & $\begin{array}{l}\stackrel{\frac{d}{d}}{\frac{d}{d}} \\
\frac{d}{d} \\
\frac{\mathbb{d}}{0} \frac{\pi}{d} \\
\frac{\pi}{\omega}\end{array}$ & 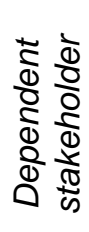 \\
\hline Students & $x$ & & & & & $x$ & $x$ & $x$ \\
\hline Graduates & $x$ & & & & $x$ & $x$ & & \\
\hline Parents (through students) & $x$ & & & & & $x$ & $x$ & $x$ \\
\hline $\begin{array}{l}\text { University employees (lecturers, management, } \\
\text { administrative staff) }\end{array}$ & $x$ & & & & $x$ & $x$ & $x$ & $x$ \\
\hline Society & & $x$ & & & $x$ & $x$ & $x$ & \\
\hline Media & & $x$ & & & $x$ & $x$ & & \\
\hline Competitors & & $x$ & & & $x$ & $x$ & & \\
\hline Labor market & & $x$ & & & $x$ & $x$ & & \\
\hline Evaluation/assessment bodies & & & $\mathrm{x}$ & $x$ & & & & \\
\hline Domestic and offshore partners & & & $x$ & $x$ & $x$ & $x$ & & \\
\hline Government & & & $x$ & $x$ & & & & \\
\hline
\end{tabular}

There are several studies that map the process of higher education service provision to define quality and the relevant stakeholders (e.g. Pereira \& Da Silva, 2003; Labanauskis \& Ginevicius, 2017). Jain et al. (2011) differentiate the students, the faculty and staff and the infrastructure as the suppliers of input, pointing out only the first two as having any kind of control. According to them, the output's 'customers' are the society and the industry since they view graduates as outputs of HE. 


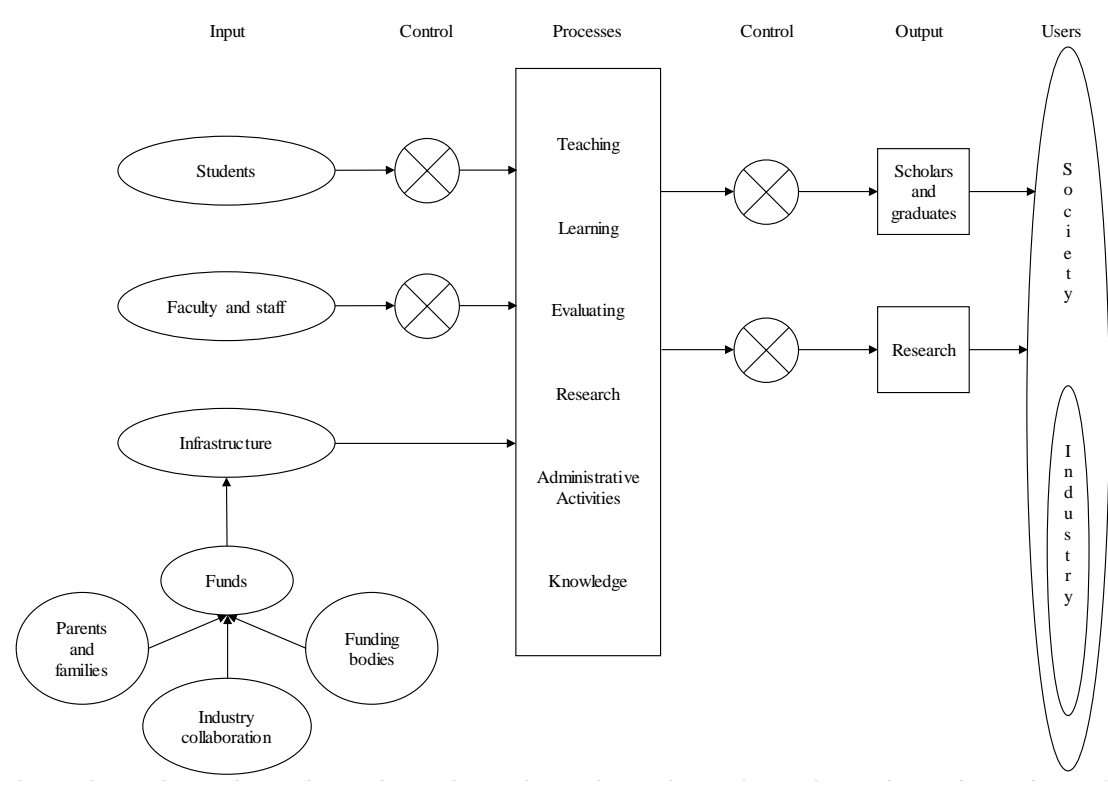

Figure 1. Processes of higher education

Source: Jain et al., 2011

Based on Jain et al.'s (2011) model and on the stakeholder groups demonstrated in Table 1, Figure 3 differentiates roles including suppliers and partners, the work group and customers.

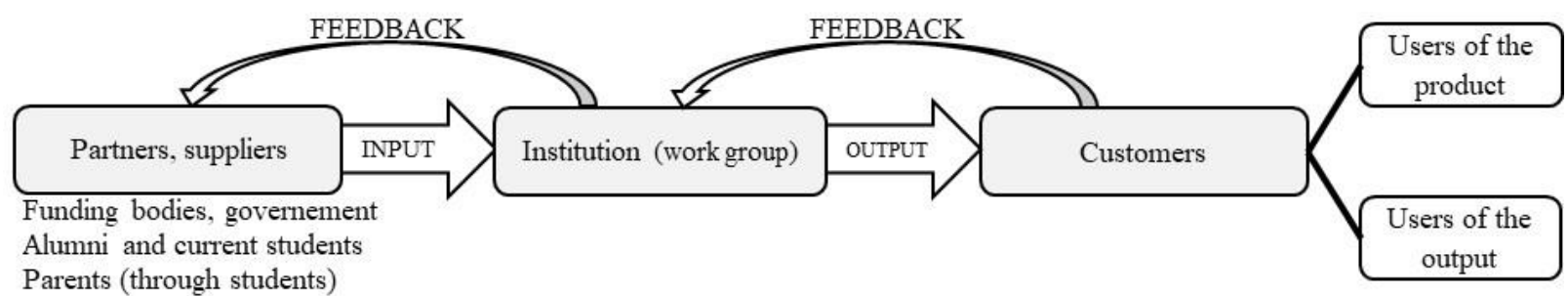

Domestic and offshore partners

Accreditors, validators, auditors and assessors

Career advisors

Figure 2. Educational services as processes

Figure 2 demonstrates the HE process in the context of the TQM philosophy emphasizing the position of students as input resources (Nasim et al., 2019) and outputs at the same time. The figure is also to summarize the conclusions of the above mentioned models by distinguishing input resources as national and offshore partners, parents, auditors, validating, accrediting and evaluating bodies, financing bodies and government, carrier advisors, graduates and current students. They provide primarily informational and financial resources to the institutional operation where the institution itself acts as a work group. The output of the process may be viewed either as knowledge (embodying finally in a degree) where students viewed as customers (output users). On the other hand, educated students could also be considered as outputs in case of which the labor market acts as a customer (outcome users).

The quality of institutional operation may be viewed at different levels (Harvey, 2003): institutional (e.g. Teeroovengadum et al., 2016), faculty /program (e.g. Mizikaci, 2006), and module/course level (e.g. Kincsesné et al., 2015; Surman \& Tóth, 2019). The process demonstrated by Figure 2 reflects the macro level of institutional operation. Viewing quality on the other two levels, only a part of the above shown partners and suppliers are relevant and the role of labor market as outcome user is getting out of the pure, direct focus as shifting towards course level. However, an institution could fulfil labor market requirements efficiently and effectively by following a bottom-up approach. This means if lecturers are conscious of labor market trends, then this approach could diffuse up to higher level of institutional operation. 
Quality could be measured in different ways (Nasim et al., 2019) by utilizing different approaches at each of the three operational levels since these interpret quality through different dimensions viewed from the aspects of different stakeholders. To investigate this issue including both the voice of students and academics, as primary stakeholders (having considerable influence in each level), questionnaires and focus group discussions were conducted which are to be discussed in the next section.

\section{Methodology}

The primary aim of the conducted student survey was to point out the differences between the three operational levels through quality attributes by focusing on the students' point of view. The survey conducted with student participation consisted of two parts: a first free thinking session and a ranking session. In the free thinking stage, students were invited to define individually the 3 most important quality characteristics associated with the different operational levels. The second phase included the most frequently referenced quality attributes according to the state of the art differentiated by the operational levels by listing 19 features on institutional, 14 characteristics on program and 17 attributes on course level (see Table 2) (e.g. Stewart \& Walsh, 1989; Owlia \& Aspinwall, 1996; Navarro et al., 2005; Douglas et al., 2008; Butt \& Rehman, 2010; Jain et al., 2011; Ibrahim et al., 2012; Seesy et al., 2018; etc.). In this part, respondents were required to rank the 3 most important attributes from the lists related to the separate level.

Table 2. Quality attributes at different levels of institutional operation

\begin{tabular}{|c|c|c|}
\hline Institution & Program & Course \\
\hline $\begin{array}{ll}\text { - } & \text { career opportunities } \\
\text { - } & \text { scientific work and } \\
\text { - } & \text { infrastructure, equipment } \\
\text { - } & \text { trust } \\
\text { - } & \text { commitment to } \\
\text { - } & \text { improvement } \\
\text { - } & \text { internationalism } \\
\text { - } & \text { active student life } \\
\text { - } & \text { word-of-mouth } \\
\text { - } & \text { industrial relationships } \\
\text { - } & \text { safety } \\
\text { - } & \text { joint services e.g. dormitory } \\
\text { - } & \text { location, e.g. public } \\
\text { - } & \text { transportation } \\
\text { - } & \text { social engagement } \\
\text { - } & \text { number of programs } \\
\text { - } & \text { library services } \\
\text { - } & \text { administration process }\end{array}$ & $\begin{array}{l}\text { - } \quad \text { lecturer skills and abilities } \\
\text { - } \quad \text { career opportunities } \\
\text { - } \quad \text { infrastructure, equipment } \\
\text { - } \quad \text { trust } \\
\text { - } \quad \text { curriculum } \\
\text { - } \quad \text { internationalism } \\
\text { - } \quad \text { further study opportunities } \\
\text { - } \quad \text { word-of-mouth } \\
\text { - } \quad \text { feedety } \\
\text { - } \quad \text { scholarship opportunities } \\
\text { - } \text { number of courses }\end{array}$ & $\begin{array}{ll}\text { - } & \text { lecturer skills and abilities } \\
\text { - } & \text { scientific work and } \\
\text { - } & \text { infrastructure, equipment } \\
\text { - } & \text { reliability } \\
\text { - } & \text { understandability } \\
\text { - } & \text { commitment to } \\
\text { - } & \text { improvement } \\
\text { - } & \text { knowlness, utilizable } \\
\text { - } & \text { empility to arise interest } \\
\text { - } & \text { theory-practice ratio } \\
\text { - } & \text { responsiveness } \\
\text { - } & \text { safety } \\
\text { - } & \text { accuracy } \\
\text { - } & \text { novelty, modernity } \\
\text { - } & \text { accessibility } \\
\text { - } & \text { personal attention } \\
\text { - } & \text { feedback and reclamation } \\
& \text { handling }\end{array}$ \\
\hline
\end{tabular}

The questionnaire was filled in by 258 Hungarian and 78 foreign students who were invited to respond during the Quality Management and Management and Business Economics titled courses (average response rate is around $49 \%$ ). The demographic characteristics are shown in Table 3.

Table 3. Respondents' demographic characteristics

\begin{tabular}{|l|l|l|l|}
\hline & Foreigner & Hungarian & Total \\
\hline
\end{tabular}




\begin{tabular}{|c|c|c|c|}
\hline \multicolumn{4}{|c|}{ Gender } \\
\hline Female & 35 & 52 & 87 \\
\hline Male & 43 & 206 & 249 \\
\hline \multicolumn{4}{|c|}{ Level of study } \\
\hline Bachelor & 57 & 256 & 313 \\
\hline Master & 21 & 1 & 22 \\
\hline Undivided & - & 1 & 1 \\
\hline \multicolumn{4}{|c|}{ Field } \\
\hline Engineering & 56 & 254 & 310 \\
\hline Business and management & 22 & 4 & 26 \\
\hline \multicolumn{4}{|c|}{ Work experience } \\
\hline Already have & 48 & 32 & 80 \\
\hline No work experience at all & 30 & 226 & 256 \\
\hline \multicolumn{4}{|c|}{ Course } \\
\hline Management and Business Economics & 53 & 249 & 302 \\
\hline Quality Management & 25 & 9 & 34 \\
\hline SUM & 78 & 258 & 336 \\
\hline
\end{tabular}

In the meantime, focus group discussions were organized including $\mathrm{PhD}$ students and lecturers from the Department of Management and Business Economics at the investigated university. From the results of the focus group discussions, affinity diagrams were constructed the headings of which were compared to the state of the art dimension rankings.

\section{Results}

\subsection{Student survey}

The responses of the first free thinking session defined quality in various ways, the most popular categories are listed in Table 4. Each respondent had to give three ideas in connection with quality at every operational level. Hungarian students listed 774, while foreign students provided 234 ideas. When summarizing the answers, the first step was to look for the same ideas and to group the synonyms. Table 4 demonstrated those features and characteristics that appeared with the highest frequency. The way how Hungarian and foreign students articulate quality shows many similarities, however, it is worth mentioning that e.g. career opportunities were mentioned more times by foreign students.

Table 4. Most frequent quality attributes provided in the free thinking session

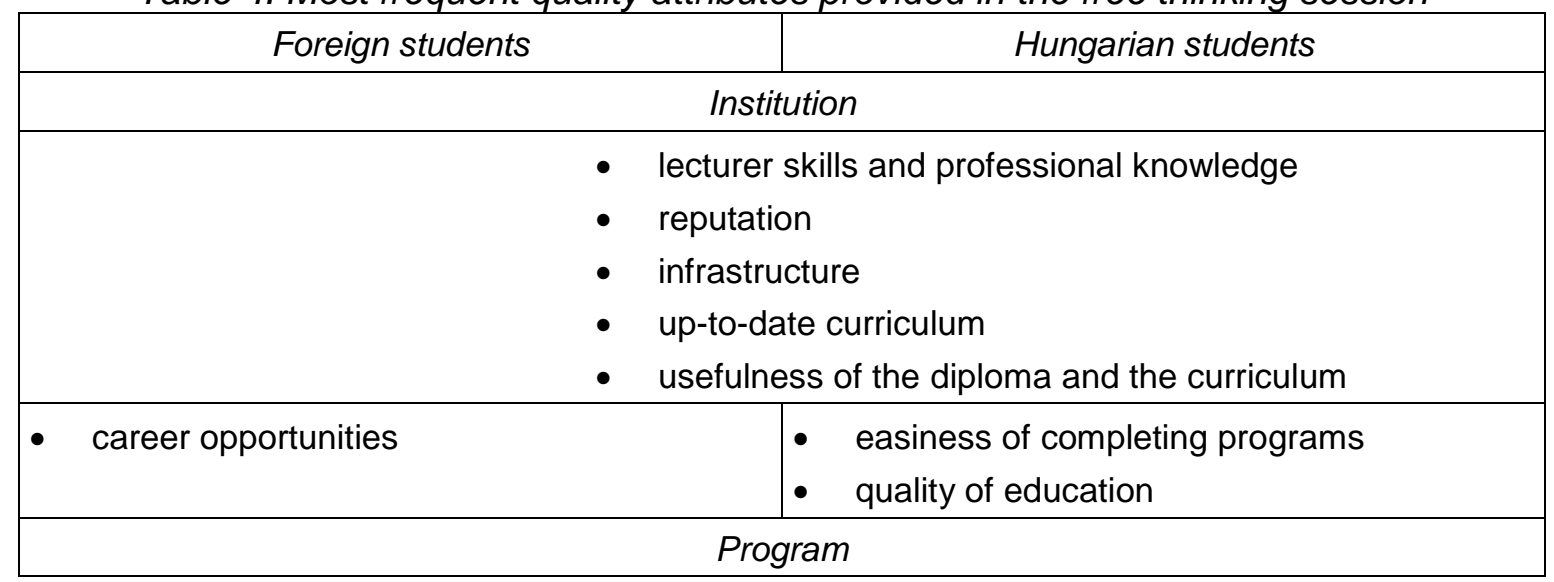




\begin{tabular}{|c|c|}
\hline & $\begin{array}{ll}\text { - } & \text { diversity } \\
\text { - } & \text { up-to-date curriculum and knowledge } \\
\text { - } & \text { lecturer skills and professional knowledge } \\
\text { - } & \text { interesting }\end{array}$ \\
\hline $\begin{array}{l}\text { - } \text { career opportunities } \\
\text { - } \quad \text { reliability }\end{array}$ & $\begin{array}{ll}\text { - } & \text { reputation } \\
\text { - } & \text { proper and suitable processes } \\
\text { - } & \text { usefulness of the degree and the } \\
& \text { curriculum }\end{array}$ \\
\hline \multicolumn{2}{|r|}{ Course } \\
\hline \multicolumn{2}{|r|}{$\begin{array}{ll}\text { - } & \text { lecturer skills } \\
\text { - } & \text { usefulness } \\
\text { - } & \text { ability to arise interest } \\
\text { - } & \text { proper and suitable processes } \\
\text { - } & \text { understandability } \\
\text { - } & \text { practice-oriented }\end{array}$} \\
\hline $\begin{array}{l}\text { - } \text { career opportunities } \\
\text { - } \text { easiness of fulfilling the course } \\
\text { - } \text { syllabus }\end{array}$ & $\begin{array}{l}\text { - } \quad \text { diversity } \\
\text { - } \quad \text { up-to-date syllabus and knowledge }\end{array}$ \\
\hline
\end{tabular}

Based on the most frequent ideas given in the free thinking session, institutional reputation, and the infrastructure are the most perceived attributes of quality at institutional level, while the course level view of quality focused more on the skills and professionalism of the academic staff. Regarding the quality features of the curricula and the related syllabuses, it is easy to see that as we reach lower levels of operation, the most features refer to the quality lecturing style. What is more surprising that student responses in connection with quality have not referred to student performance assessments at all.

In the second part of surveying where students chose the 3 most important dimensions from the listed attributes, several similarities and differences could also be detected. The table in the Appendix is to demonstrate the diversity of features emerging from the literature research.

At the macro level, career opportunities, reliability, the scientific work and the reputation of the academic staff, and the institutional commitment to improvement were highlighted most frequently. At the program / faculty level, the skills and abilities of the lecturers and the curriculum appeared besides the career opportunities and the scientific work and reputation of the academic staff (which appeared on institutional level as well). The fact that the skills and abilities of the academics were ranked the highest both by the Hungarian and the foreign respondents implies that at program level the 'style' of lecturing is more important than the lecturers' professional reputation which was pointed out at institutional level as one of the most important attributes. By following a top-down approach and reaching the course level, even more attention should be paid to the knowledge transferring ability of the lecturers, since understandability, the skills and abilities of the lecturers and usefulness were ranked as highest. At this level, 'reliability' and 'commitment to improvement' were ranked lower than at institutional level. It is worth pinpointing that in case of courses the academic work and publications of the lecturers as attributes were neglected, while it contributes to 'the degree to which education is correct, accurate and up to date' (Owlia \& Aspinwall, 1996) and is an important indicator in various $\mathrm{HE}$ institution rankings (Quacquarelli Symonds (QS), Times Higher Education World University Rankings (THE), Center for World University Rankings (CWUR)). There was no significant difference between the rankings of foreign and Hungarian students. This is confirmed by the Spearman rank-order correlation results as well (large positive correlation (institutional level: $r_{s}=0.8178, p=0.000$, program level: $r_{s}=0.848, p=0.000$, course level: $\left.r_{s}=0.828, p=0.000\right)$ ). 
When comparing the results emerging from the first and second part of surveying, several highly ranked quality attributes of the second part appeared in the first, free thinking part. There are some attributes highlighted in the literature which have not appeared in any part when surveying our students (e.g. trust, joint services, social engagement). This phenomenon affects primarily the macro level, while at course level all state of the art attributes was mentioned in the free thinking part except for 'handling feedback and reclamations' and 'accessibility'. This implies that the evaluation of quality at institutional level should not be dominated by the students' view. Due to the existence of information asymmetry students do not have a full understandability of institutional operation. To further explore this issue, focus group discussions were held.

\subsection{Focus group discussions}

Three focus group discussions were held to investigate the differences between the perceptions of lecturers and students in terms of the three operational levels' primary quality attributes. The first group consisted of $2 \mathrm{PhD}$ students and an assistant lecturer in order to track how opinions change while 'transforming' from student to lecturer. The other two focus groups included professors and researchers with higher levels of lecturing experience, one including academics from an elder and the other from a younger generation. During the free thinking session, focus group participants identified quality attributes related to the three distinct levels ( $\mathrm{min} .5$ attributes per level). In the second part, participants discussed the emerged ideas and then grouped them together into an affinity diagram.

Considering course level, the three different focus groups listed similar ideas related mainly to the curriculum and to the knowledge transferring style of the lecturer mentioning the theory-practice ratio, diversity, self-improvement, interactivity, improvement, logic, actuality (modernity), depth and quality of the curriculum, number of students, infrastructure.

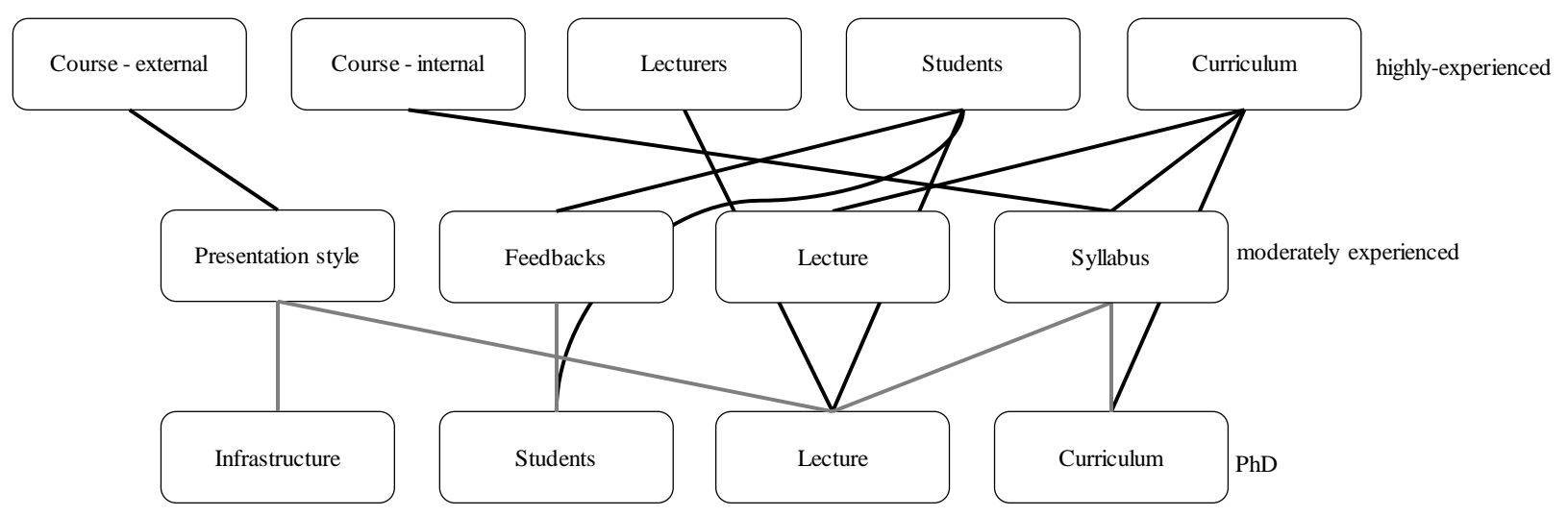

Figure 3. Affinity diagram headings on course level

At program level, the importance of labor market feedback has not been emphasized by PhD students. The PhD student group narrowed the quality features of programs primarily to courses and curricula. The role of lecturers (when examining quality at course level) has not been mentioned in the focus group of mid-experienced lecturers. The constructed affinity diagrams focused primarily on the following characteristics: recognition and reputation of the lecturers and programs, graduate career tracking and admission trends, course-specific flexibility, customization and popularity, and infrastructure. 


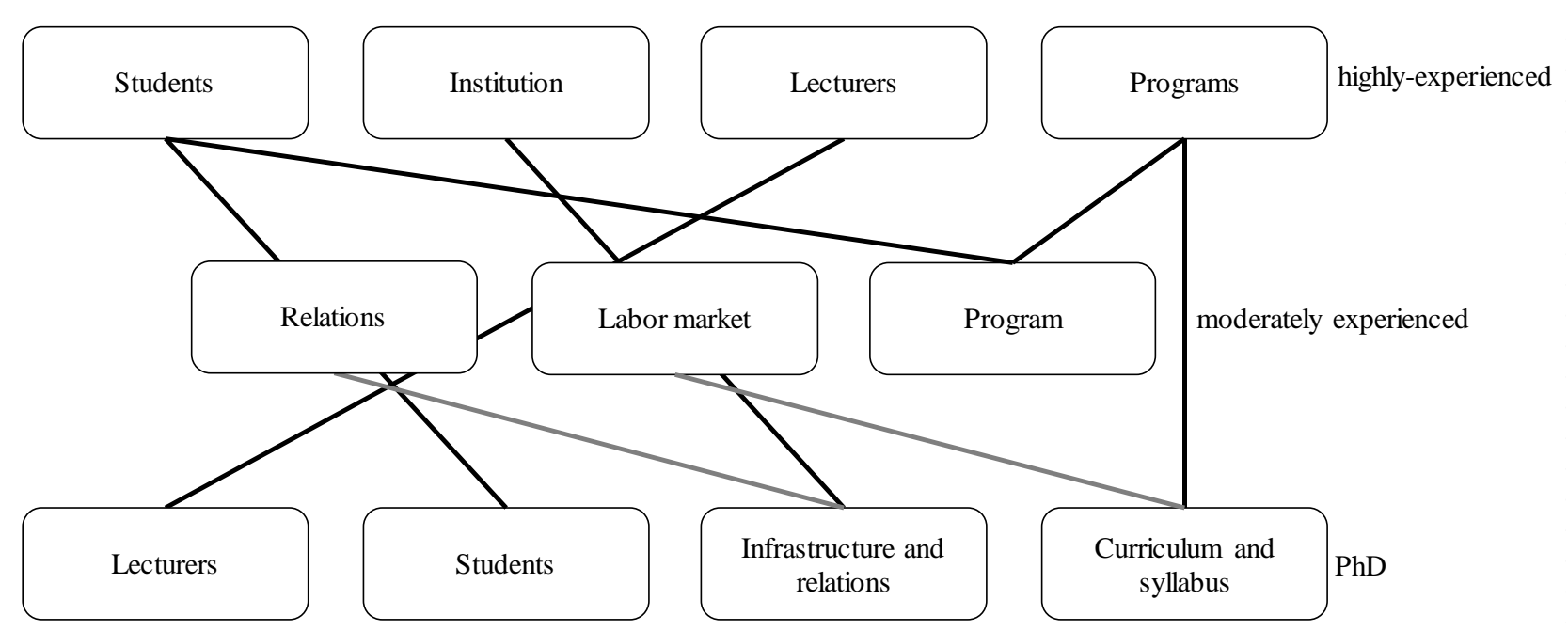

Figure 4. Affinity diagram headings on program level

The affinity diagrams focusing on institutional level primarily reflected to the international and scientific relations of the institution, to the recognition, reputation and connected publications of the lecturers, the value of the various degrees, the modernity (actuality) of the knowledge provided by the various programs and the features of the admission process. It is worth highlighting that only the syllabus was mentioned by the highly experienced group of lecturers, while the curriculum did not appear at all.

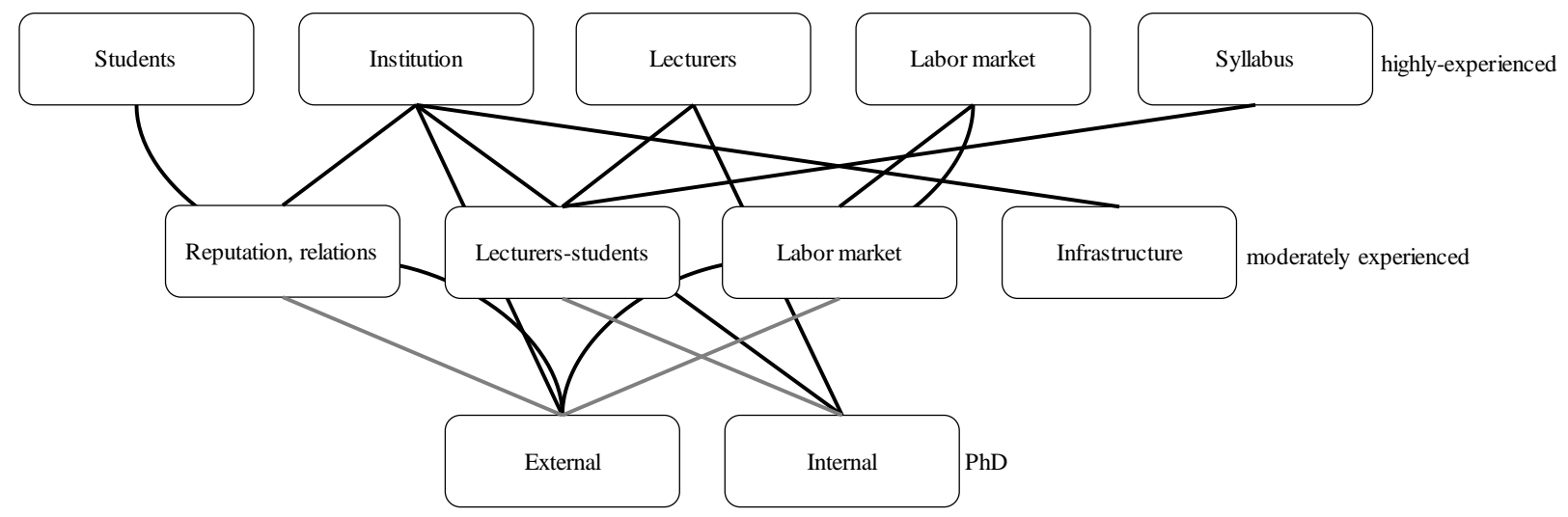

Figure 5. Affinity diagram headings on institution level

The comparison of the attributes highlighted by the focus groups and the state of the art (included also in the second part of the student survey) delivers similar results as the comparison between the two stages of surveying.

Many state of the art quality attributes were highlighted both in the free thinking part of student surveying and in the focus group work as well (see Table in the Appendix). It can be concluded that the highly experienced group of lecturers was closest to the knowledge embedded in the literature and overlapped the best with students' free thinking results. Overall, student responses emerging in the free thinking session were closest to the features arising from the state of the art taking into consideration that far more students were involved in the survey than lecturers participating in the focus group sessions. From the 50 listed quality attributes (see Table 2), students specified 36 in the free thinking session, while PhD students and mid-experienced lecturers listed 25 and highlyexperienced lecturers assigned 31 features. 


\section{Conclusions}

The demographic changes and the recent trends turning up in higher education have all been shifting this sector to break down the traditional assumptions and to become an integral part of both the society and the economy (Polónyi, 2006). HEls must act as service providers: there is an extensive pressure on them to meet the needs and expectations of their stakeholders as much as possible. The increasing competition both on national and international levels, the growing number of institutions, the rising demand for domestic institutions to appear on the international scene, and the need to enhance their competitiveness require institutional management to pay more attention to the quality of educational service and to the service quality perceptions of students.

The primary purpose of this research was to highlight the existence of quality attribute differences among the different operational levels by listening to the voice of students and lecturers as well.

Based on the results of the applied survey and the three focus group discussions, it can be concluded that the focus of each level includes primarily the quality features listed in Table 5.

Table 5. Concluded dimensions of the three operational levels

\begin{tabular}{|c|c|c|}
\hline Institution & Program & Course \\
\hline $\begin{array}{ll}\text { - } & \text { career opportunities (during } \\
& \text { and after) } \\
\text { - } & \text { scientific work and } \\
\text { - } & \text { infutation of academic staff } \\
\text { - } & \text { reliability } \\
\text { - } & \text { institution's commitment to } \\
\text { improvement } \\
\text { - } & \text { institutional reputation } \\
\text { - } & \text { internationalism } \\
\text { - } & \text { industrial relationships } \\
\text { - } & \text { enrolment process }\end{array}$ & $\begin{array}{ll}\text { - } & \text { lecturer skills and abilities } \\
\text { - } & \text { career opportunities (by the } \\
\text { program) } \\
\text { - } & \text { scientific work and } \\
& \text { reputation of academic staff } \\
\text { - } & \text { infrastructure, equipment } \\
\text { - } & \text { curriculum } \\
\text { - } & \text { internationalism } \\
\text { - } & \text { program reputation }\end{array}$ & $\begin{array}{ll}\text { - } & \text { lecturer skills and abilities } \\
\text { - } & \text { infrastructure, equipment } \\
\text { - } & \text { reliability } \\
\text { - } & \text { understandability (syllabus } \\
\text { - } & \text { and lecture) } \\
\text { - } & \text { improver's commitment to } \\
\text { - } & \text { usefulness and utilizable } \\
\text { - } & \text { ability to arise interest } \\
\text { - } & \text { theory-practice ratio } \\
\text { - } & \text { novelty and modernity } \\
\text { (value-added received } \\
\text { during the course) }\end{array}$ \\
\hline
\end{tabular}

These features demonstrate those quality attributes to which institutions should pay attention at each level of operation when managing quality.

However, the identification of these attributes is not enough to establish an implementable framework. The various stakeholders align with the various HE services have to be associated with the different levels of operation. What is more, their needs and expectations should be weighted as well as the different quality attributes. The demographic features of the stakeholders are also important since that could bias the results. For a successful framework, validity and reliability have to be also evaluated (Ramlo, 2017).

Concerning future research directions, with defining the three groups of quality attributes, the next step has to be the determination of the weights by applying e.g. Likert scaling. What the voice of students is concerned, a new, more sophisticated questionnaire will be developed, while the interpretation of quality attributes needs further investigation. Personal interviews are also planned with labor market participants and with the heads of department of the university under investigation (based on the results of literature research, e.g. Reid, 2008).

\section{Acknowledgment}

Supported by the ÚNKP-19-3 New National Excellence Program of the Ministry for Innovation and Technology.

\section{References}


[1] Bennett, R. \& Ali-Choudhury, R. (2009). Prospective students' perceptions of university brands: an empirical study. Journal of Marketing for Higher Education, 19(1), 85-107. doi:10.1080/08841240902905445

[2] Bhuian, S. N. (2016). Sustainability of Western branch campuses in the Gulf Region: Students' perspectives of service quality. International Journal of Educational Development, 49, 314-323.

doi:https://doi.org/10.1016/j.ijedudev.2016.05.001

[3] Butt, B. Z. \& Rehman, K. (2010). A study examining the students' satisfaction in higher education. Procedia-Social and Behavioral Sciences, 2(2), 5446-5450. doi:https://doi.org/10.1016/j.sbspro.2010.03.888

[4] Clayson, D. E. \& Haley, D. A. (2005). Marketing Models in Education: Students as Customers, Products, or Partners. Marketing Education Review, 15(1), 1-10. doi:https://doi.org/10.1080/10528008.2005.11488884

[5] Douglas, J., McClelland, R. \& Davies, J. (2008). The development of a conceptual model of student satisfaction with their experience in higher education. Quality Assurance in Education, 16(1), 19-35. doi:10.1108/09684880810848396

[6] Fassin, Y. (2009). The Stakeholder Model Refined. Journal of Business Ethics, 84, 113-135. doi:10.1007/s10551008-9677-4.

[7] Fosu, F. F. \& Owusu, B. K. (2015). Understanding Ghanaian students' perception of service quality in higher education. European Journal of Business Management, 7(9), 96-105.

[8] Gilroy, D. P., Long, P., Rangevroft, M. \& Tricker, T. (1999). The evaluation of course quality through a service template. Evaluation, 5(1), 80-91. doi:https://doi.org/10.1177/13563899922208832

[9] Guilbault, M. (2016). Students as customers in higher education: reframing the debate. Journal of Marketing for Higher Education, 26(2), 132-142. doi:10.1080/08841241.2016.1245234

[10] Guolla, M. (1999). Assessing the Teaching Quality to Student Satisfaction Relationship: Applied Customer Satisfaction Research in the Classroom. Journal of Marketing Theory and Practice, 7(3), 87-97. doi:https://doi.org/10.1080/10696679.1999.11501843

[11] Gupta, P. \& Kaushik, N. (2018). Dimensions of service quality in higher education - critical review, International Journal of Educational Management, 32(4), 580-605. doi:https://doi.org/10.1108/IJEM-03-2017-0056

[12] Harvey, L. (2003). Student Feedback. Quality in Higher Education, 9(1), 3-20. doi:10.1080/13538320308164

[13] Ibrahim, M. Z., Rahman, M. N. A. and Yasin, R. M. (2012). Assessing students' perceptions of service quality in technical Educational and Vocational Training (TEVT) Institution in Malaysia. International Conference on Teaching and Learning in Higher Education in conjunction with Regional Conference on Engineering Education and Research in Higher Education, Procedia - Social and Behavioral Sciences, 56, 272-283. doi:https://doi.org/10.1016/j.sbspro.2012.09.655

[14] Jain, R., Sinha, G., \& Sahney, S. (2011). Conceptualizing service quality in higher education. Asian Journal on Quality, 12(3), 296-314. doi:https://doi.org/10.1108/15982681111187128

[15] Kincsesné, V. B., Farkas, G. \& Málovics, É. (2015). Student evaluations of training and lecture courses: development of the COURSEQUAL method. International Review on Public and Nonprofit Marketing, 12, 79-88. doi:10.1007/s12208-015-0127-6

[16] Kováts, G. (2016). Trendek és szándékok az európai felsőoktatás minőségbiztosításában, In book: A felsőoktatás minőségbiztosítási horizontja - A megújított európai standardok és irányelvek müködése, alkalmazása (in Hungarian)

[17] Kováts, G. \& Takács, E. (2016). Értékelési eljárások a felsőoktatásban, In book: A felsőoktatás minőségbiztosítási horizontja - A megújított európai standardok és irányelvek működése, alkalmazása (in Hungarian)

[18] Labanauskis, R. \& Ginevicius, R. (2017). Role of stakeholders leading to development of higher education services. Engineering Management in Producation and Services, 9(3), 63-75. doi:10.1515/emj-2017-0026

[19] Mainardes, E. W., Alves, H. \& Raposo, M. (2012). A model for stakeholder classification and stakeholder relationships. Management Decision, 50(10), 1861-1879. doi:https://doi.org/10.1108/00251741211279648

[20] Mark, E. (2013). Student satisfaction and the customer focus in higher education. Journal of Higher Education Policy \& Management, 35(1), 2-10. doi:https://doi.org/10.1080/1360080X.2012.727703

[21] Mattah, P. A. D., Kwarteng, A. J. \& Mensah, J. (2018). Indicators of service quality and satisfaction among graduating students of a higher education institution (HEI) in Ghana. Higher Education Evaluation and Development, 12(1), 36-52. doi:https://doi.org/10.1108/HEED-10-2017-0006

[22] Mizikaci, F. (2006). A systems approach to program evaluation model for quality in higher education. Quality Assurance in Education, 14(1), 37-53. doi:https://doi.org/10.1108/09684880610643601

[23] Nasim, K., Sikander, A. \& Tian, X. (2019). Twenty years of research on total quality management in Higher Education: A systematic literature review. Higher Education Quarterly, 00, 1-23. doi:10.1111/hequ.12227

[24] Navarro, M. M., Iglesias, M. P. \& Torres, P. R. (2005). A new management element for universities: satisfaction with the offered courses. International Journal of Educational Management, 19(6), 505-526. doi:https://doi.org/10.1108/09513540510617454

[25] Nell, C. E. \& Cant, M. C. (2014). Determining student perceptions regarding the most impoartant service features and overall satisfaction with the service quality of a higher education institution. Management, 19(2), 63-87.

[26] Olaskoaga-Larrauri, J., Barrenetxea-Ayesta, M., Cardona-Rodríguez, A., Campo, J. J. M. \& Barandiaran-Galdós, M. (2016). Between Efficiency and Transformation: the opinion of deans on the meaning of quality in higher education. European Journal of Education, 51(2), 257-269. doi:10.1111/ejed.12141

[27] Owlia, M. S. \& Aspinwall, E. M. (1996). A framework for the dimensions of quality in higher education. Quality Assurance in Education, 4(2), 12-20. doi:https://doi.org/10.1108/09684889610116012

[28] Pereira, M. A. \& Da Silva, M. T. (2003). A Key Question for Higher Education: Who are the customers? Proceedings of the $31^{\text {st }}$ Annual Conference of the Producation and Operations Management Society, POM-2003, Atlanta, GE. 
[29] Polónyi, I. (2006). A munkaerőpiacra orientált felsőoktatási minőségbiztosítás. In: Bálint, J., Polónyi, I. \& Siklós, B. (szerk.) A felsőoktatás minősége. Felsőoktatási Kutatóintézet, 10-38.

[30] Ramlo, S. (2017). Improving Student Evaluation of Teaching: Determining Multiple Perpectives within a Course for Future Math Educators. Journal of Research in Education, 27(1), 49-78.

[31] Reid, N. (2008). Quality Assurance in Higher Education in Pakistan - Focus on the Learner. Paper presented at the $2^{\text {nd }}$ International Conference on Assessing Quality in Higher Education, ICAQHE.

[32] Ruben, B. D. (2018). Quality in higher education, New York, NY: Routledge, doi:https://doi.org/10.4324/9781351293563

[33] Seesy, N. A. E. E, Hussein, R. G. \& Alzahrani, A. E. (2018). Undergraduate nursing students' perceptions of educational service quality at Alexandria University, Egypt. Journal of Nursing Education and Practice, 8(1), 37-45. doi:10.5430/jnep.v8n1p37

[34] Stewart, J. D. \& Walsh, K. (1989). In Search of Quality. Local Government Training Board, Luton, In: Abdullah, F. (2006) The development of HEdPERF: a new measuring instrument of service quality for the higher education sector, International Journal of Consumer Studies, 30(6), 569-581.

[35] Surman, V. \& Tóth, Zs .E. (2019) Developing a Service Quality Framework for a Special Type of Course. Periodica Polytechnica- Social and Management Sciences, 27(1), 66-86. doi:https://doi.org/10.3311/PPso.12201.

[36] Teeroovengadum, V., Kamalanabhan, T. J. \& Seebaluck, A. K. (2016). Measuring service quality in higher education: Development of a hierarchical model (HESQUAL). Quality Assurance in Education, 24(2), $244-258$. doi:10.1108/QAE-06-2014-0028

\section{Appendix}

\begin{tabular}{|c|c|c|c|c|c|}
\hline Institution - Dimensions & Foreigners & Hungarians & $\begin{array}{c}\text { Highly- } \\
\text { experienced }\end{array}$ & $\begin{array}{l}\text { Moderately } \\
\text { experienced }\end{array}$ & $P h D$ \\
\hline career opportunities & 1 & 1 & yes & yes & yes \\
\hline reliability & 2 & 2 & yes & yes & yes \\
\hline $\begin{array}{l}\text { scientific work and reputation of } \\
\text { academic staff }\end{array}$ & 3 & 4 & yes & yes & yes \\
\hline commitment to improvement & 9 & 3 & yes & yes & yes \\
\hline institutional reputation & 5,5 & 7 & yes & yes & yes \\
\hline active student life & 4 & 9 & yes & & \\
\hline trust & 8 & 5 & & & \\
\hline infrastructure, equipment & 7 & 6 & yes & yes & yes \\
\hline internationalism & 5,5 & 10,5 & yes & yes & yes \\
\hline industrial relationships & 12,5 & 8 & yes & yes & yes \\
\hline joint services e.g. dormitory & 12,5 & 10,5 & yes & & \\
\hline word-of-mouth & 10 & 13 & & & \\
\hline safety & 16,5 & 12 & & & \\
\hline social engagement & 12,5 & 16 & & & \\
\hline enrolment process & 15 & 15 & & yes & yes \\
\hline number of programs & 12,5 & 18 & & & \\
\hline location, e.g. public transportation & 16,5 & 14 & & & \\
\hline administration process & 19 & 17 & & & \\
\hline library services & 18 & 19 & & & \\
\hline Program - Dimensions & Foreigners & Hungarians & $\begin{array}{c}\text { Highly- } \\
\text { experienced }\end{array}$ & $\begin{array}{l}\text { Moderately } \\
\text { experienced }\end{array}$ & $P h D$ \\
\hline lecturer skills and abilities & 1 & 1 & yes & yes & yes \\
\hline career opportunities & 2 & 3 & yes & yes & yes \\
\hline curricula & 5 & 2 & yes & yes & yes \\
\hline
\end{tabular}




\begin{tabular}{|c|c|c|c|c|c|}
\hline $\begin{array}{l}\text { scientific work and reputation of } \\
\text { academic staff }\end{array}$ & 3,5 & 4 & yes & yes & yes \\
\hline infrastructure, equipment & 3,5 & 6 & yes & & yes \\
\hline program reputation & 6 & 7 & yes & yes & yes \\
\hline trust & 9,5 & 5 & & & \\
\hline scholarship opportunities & 8 & 10 & & & \\
\hline internationalism & 7 & 11 & yes & yes & yes \\
\hline feedbacks given to students & 9,5 & 9 & yes & & \\
\hline further study opportunities & 11 & 8 & & & yes \\
\hline word-of-mouth & 12 & 12 & & & \\
\hline safety & 14 & 13 & & & \\
\hline number of courses & 13 & 14 & & & \\
\hline Course - Dimensions & Foreigners & Hungarians & $\begin{array}{c}\text { Highly- } \\
\text { experienced }\end{array}$ & $\begin{array}{l}\text { Moderately } \\
\text { experienced }\end{array}$ & $P h D$ \\
\hline understandability & 1 & 1 & yes & yes & yes \\
\hline lecturer skills and abilities & 2 & 3 & yes & yes & yes \\
\hline usefulness, utilizable knowledge & 6,5 & 2 & yes & yes & yes \\
\hline reliability & 4 & 6 & yes & yes & yes \\
\hline empathy & 3 & 7 & & & \\
\hline ability to arise interest & 8 & 4 & yes & yes & yes \\
\hline responsiveness & 5 & 8 & & & \\
\hline theory-practice ratio & 9,5 & 5 & yes & yes & \\
\hline commitment to improvement & 6,5 & 10,5 & yes & yes & yes \\
\hline accuracy & 9,5 & 10,5 & & & \\
\hline infrastructure, equipment & 12 & 9 & yes & yes & yes \\
\hline novelty, modernity & 13 & 12 & yes & yes & yes \\
\hline personal attention & 11 & 15 & & yes & \\
\hline accessibility & 15 & 13 & & & \\
\hline feedback and reclamation handling & 15 & 14 & yes & & \\
\hline $\begin{array}{l}\text { scientific work and reputation of } \\
\text { academic staff }\end{array}$ & 15 & 17 & yes & & \\
\hline safety & 17 & 16 & & & \\
\hline
\end{tabular}

